\title{
Trivariate Modelling of the Nexus Between Financial Development, Globalization and Economic Growth: Insight from African Countries
}

\author{
Azeez Olanrewaju Ahmed \\ Department of Economics, Shenyang University of Chemical Technology, \\ Shenyang City, Liaoning Province, China. \\ Email: ahmolazdbase03@yahoo.com
}

\begin{abstract}
Financial development has been identified as main drivers of economic growth. However, empirical probe of this nexus remains inconclusiveness due use of an inappropriate proxy by previous studies, and the inability of previous studies to consider globalization in this nexus. To this end, we probe the finance-growth nexus in the presence of globalization by applying the Pooled Mean Group (PMG) estimator to a sample of 21 countries spanning 1990-2017. The empirical results affirm the supply-leading hypothesis which indicates that financial development spur economic growth. In addition, our estimate provides evidence of a positive linear relationship between globalization and economic growth. Further, results indicate that physical capital investment plays an important role in accelerating economic performance of African economies. Based on these findings, it is important for African countries to promote globalization-financial development policies in order to have access to alternative sources of external financing and attract foreign investment that can spur growth of African countries.
\end{abstract}

JEL Code: F60, G20, 040.

Keywords: Financial Development, Globalization, Economic Growth, Pooled Mean Group and African Countries.

\section{Ho to Cite}

Ahmed, A. O. (2021). Trivariate modelling of the nexus between financial development, globalization and economic growth: insight from African Countries. International Journal of Finance Research. 2(3). 129-142. DOI. https://doi.org/10.47747/ijfr.v2i3.312

\section{Introduction}

The objective of every economy is to achieve sustainable economic development because economic progress is essential for poverty reduction and infrastructure development in the long run (Shahbaz, Nasir, Hille and Mahalik, 2020). Financial development accelerate growth by mobilizing savings, encourages resource allocation, and eases divergence and management of risk (Sahay et al., 2015). Thus, a fully developed financial system fascinates investment, lowers information cost and enhances growth (Levine, 2005 and Ang, 2008a). 
Theoretically, relationship between finance and economic growth has been a controversial issue as it has led to the establishment of three positions namely; supply-leading, demandfollowing and neutrality hypothesis. The supply-leading hypothesis posits that finance augment growth while the demand-following hypothesis contend that growth give rise to the demand for financial services and the neutrality theory speculates that no causation between finance and growth.

Globalization entails the process whereby corporations and government connect across the globe (Zaidi, Zafar, Shahbaz \& Hou, 2019). It promotes economic growth by allowing international investors access to local financial markets, improving the quality of financial institutions, and enhancing economic integration through trade and financial flows (Mishkin, 2009; Kandil et al. 2015 and Atil et al., 2020). Rousseau and Sylla (2003) also asserts that globalization gives access to innovative products, investment, and new ideas which increases per-capita income in the host country.

In the existing literature, there are numerous studies with mixed results on the relationship between financial development and economic growth (Adeniyi, Oyinlola, Omisakin and Egwaikhide, 2015; Samargandi, Fidrmuc, and Ghosh, 2015; Kenza \& Eddine, 2016; Muazu and Ibrahim, 2018; Botev and Jawadi, 2019; Alimi and Adediran, 2020; Wu et al 2020; and Redmond and Nasir, 2020). The present study contends that the divergent findings recorded could be because the authors did not account for globalization in their regressions. In addition, existing empirical studies have used a single indicator to examine the financegrowth nexus. Due of complex nature of services provided by the financial system, capturing financial development with a single indicator could lead to potential bias and mislead the outcomes. To this end, this study employs financial development index of World Bank Global Financial Development index and KOF index which entails economic, social and political aspects of globalization to probe the link among financial development, globalization and economic growth in African economies. Given the motivation around the attainment of economic development, there is need to evaluate the distinctive role of financial development and globalization in African economies to help project the trend of economic performance. This empirical exercise is important to help reveal the source of economic development in African economies and guide finance and growth policies appropriately.

The rest of the paper is structured as follows. The next section takes a look at the empirical facts on globalization in finance-growth nexus. Section 3 present the methodology while section 4 focuses on result and discussion of finding and section 5 concludes the paper.

\section{Literature Review.}

Recently, the interlinkage amongst finance, globalization and economic growth has attracted great attention from scholars and policy makers. Among these is the study of Ahmed, Zhang and Cary (2021) which incorporated globalization and ecological footprint into financegrowth nexus in Japan employed ARDL and NARDL estimation technique with annual data from 1971 and 2016. Their finding established that positive and negative change to finance foster economic footprint while positive and negative changes to globalization lessening the footprint. For Malaysia, Ahmed et al (2019) applied ARDL and annual data for 1971 and 2014 to assay the nexus between globalization and the ecological footprint. They found that population density lessens ecological footprint while energy consumption and economic growth accelerate ecological footprint. The result further indicates globalization hampers ecological carbon footprint in Malaysia. On the nexus between ICT, globalization and Co2 
emission, Ahmed and le (2020) applied CUP-FM estimation technique for 6 ASEAN countries over the period of 1996 and 2017. The empirical result of the study disclosed that ICT reduces co2 emission and thereby enhance environmental quality.

Focusing on ECOWAS countries, Alimi and Adediran (2020) examined finance-growth nexus by incorporating ICT diffusion using PARDL technique spanning 2005 and 2016. The study finds that financial development retards growth while the interactive effect of financial development and ICT diffusion accelerate the growth in ECOWAS region. The study of Muhammad et al. (2016) employed panel estimation technique and discovered that financial development foster GCC economies. For China, Japan and India using bootstrapping ARDL spanning 1960 and 2016, Wu et al (2020) validates the supply-leading and demand-following hypotheses for Japan and India but support the supply-leading theory in China. For 52 middle-income nations spanning the period of 1980 and 2008, Samargandi, Fidrmuc, and Ghosh (2015) discover an inverse link between finance and growth in the long run. Kenza \& Eddine (2016) show that finance impede growth in MENA countries. Likewise, Adeniyi, Oyinlola, Omisakin and Egwaikhide (2015) indicates financial development hinders growth in Nigeria.

For 100 developed and developing countries, Botev and Jawadi (2019) shows that finance stimulate economic growth in developed countries but exact an insignificant influence in close economies. For SSA countries, Brueckner and Lederman (2015) probed the linkage between trade openness and growth. They report that greater openness to international trade augment economic growth in both short-run and long run. In the same region, Muazu and Ibrahim (2018) finds that financial development hinders SSA growth when financial sector development is not complemented by real sector growth. Examining 30 countries spanning 1990 and 2016, Redmond and Nasir (2020) incorporated natural resources, trade openness, institutional quality and international trade into finance-growth nexus. Their empirical finding reveals that natural resource abundance and trade openness promotes growth while international trade and financial development inhibits growth.

Recently, Atil et al (2020) considered the link between natural resources and financial development through globalization, oil price and economic growth in Pakistan spanning 1972 and 2017. The outcome of their study suggests that natural resources, economic growth and oil price aid financial development while globalization dampen financial development. By employing ARDL, FMOLS and DOLS estimation technique, Guan, Kirikkaleli, Bibi and Zhang (2020) also investigated the same nexus in the presence of human capital in China. Their empirical result validates the demand-following and resources curse hypotheses which suggests that natural resources impedes financial development whereas globalization and human capital foster financial development in China. Osei and Kim (2020) probed the contribution of foreign direct investment in finance-growth nexus for 62 middle- and highincome countries between 1987 and 2016. Their panel threshold methodology results suggested foreign direct investment improves economic growth but retards economic growth whenever financial development exceeds the threshold of 95\%. For 40 African countries, Ibrahim and Sare (2018) explored the determinants of financial development and established that trade openness and human capital stimulates Africa's financial development.

Using a sample of 23 European countries spanning 1989 and 2016, Nasreen, Mahalik, Shahbaz and Abbas (2020) employed GMM estimation to analyze the linkage between Financial Globalization, Institutions, Economic Growth and financial sector development. 
Their empirical finding indicates that financial globalization inhibits financial development while institutions support financial inflows and augment financial development in European countries. In a related study, Nasreen et al. (2015) explore the linkages between financial development, institutions, globalization and economic growth. The finding of the PVAR technique reveals that globalization promote financial development through financial reforms and thereby spur economic growth. With the aid of Westerlund panel cointegration test and annual data from 1984 to 2008, Law et al. (2015) assessed the nexus between globalization, institutional reforms and financial development in East Asian economies. The study discovered that globalization strengthen financial development via institutional reforms. However, in India, Shahbaz et al. (2018a) estimated the link between globalization, institutional quality, economic growth and financial development. The result of the study reveals that globalization and institutional quality have detrimental effects on financial development whereas economic growth accelerates financial development.

By applying panel cointegration and causality methodologies for 32 developing and developed countries, Kandil et al. (2015) examined the role of globalization (proxied by globalization index) on financial development. The empirical result of the study suggests that globalization hinders financial development while financial development spurs globalization by relaxing the of constraints of external financing. Further, Kandil et al. (2017) probe the influence of globalization in the finance-growth nexus in China and India. The outcome of their study shows that globalization spurs economic growth in India but hampers growth in China. Concentrating on 3 economic blocs (BRCIS, MINTS and ECOWAS), Muye and Muye (2017) investigated the relationship between financial development, institutional quality and globalization. Their empirical result indicates that globalization promotes financial and quality institution boosts globalization-financial development nexus. The outcome of the study of Balcilar et al. (2019) indicates that economic globalization stimulates by improving the effectiveness of financial institutions in 36 developed and developing countries. In investigating the association between environmental degradation, globalization, financial development, economic growth and energy consumption in India over the period of 1980 and 2015, Sethi, Chakrabarti and Bhattacharjee (2020) employed ARDL technique and finds that globalization, economic growth increased energy consumption and degrades the environment. Likewise, Shahbaz, et al. (2020) employs Bootstrapping ARDL methodology to examine the link among economic growth, R\&D expenditures, financial development, and energy consumption and carbon dioxide emissions in UK. According to their empirical finding, energy consumption and financial development degrades the environment while $\mathrm{R} \& \mathrm{D}$ expenditures reduce $\mathrm{CO} 2$ emissions. By incorporating corruption into finance-growth linkage in 142 countries spanning 2002 and 2016, Song, Chang and Gong (2020) established that economic growth strengthens financial development in both developed and developing countries while corruption worsen financial development in developing countries.

In sum, the above literature suggests a diverse finding on the nexus between financial development and growth and its determinants across countries. To the best of our knowledge, no research work has been carried out on African countries using comprehensive globalization and financial development index, making it a motivation. 


\section{Research Method}

For this study, we analyze annual data from 1990 to 2018 for 25 African economies to probe the finance-growth nexus in the presence of globalization. The justification for the selected countries and time frame is based on availability of data. In order to simplify coefficient interpretations and overcome the problem of heteroscedasticity, all the dataset is transformed to natural logarithm (Faisal, Sulaiman and Tursoy, 2019). The data employed in this study are economic growth (proxied by GDP per capita measured at constant A2010 US Dollars), Following Dreher (2006) and Gygli et al. (2019), globalization is measure as economic, social and political globalization. In line with Sahay et al (2015) and Nasreen et al., (2020), financial development is measured by financial access (proxied by commercial bank branches per 100,000 adults and ATMS per 100,000 adults), financial depth (proxied by private-sector credit to GDP, stock market capitalization to GDP, stock traded to GDP and liquid liability to GDP) and efficiency (proxied by stock market turnover ratio). Data on economic growth is sourced from World Bank Indicator 2020 edition while data on globalization is collected from the globalization KOF index by Dreher (2006) and Gygli et al. (2019). Lastly, data on financial development is collected from World Bank Global Financial Development Database (GFDD). The selected countries for this study are: Angola, Algeria, Benin, Botswana, Cameroon, Cote d'lvoire, Egypt, Ethiopia, Gabon, Ghana, Kenya, Morocco, Mali, Mauritania, Mauritius, Namibia, Nigeria, Senegal, Seychelles, Tunisia and South Africa.

\subsection{Econometric Strategy}

Building on the previous empirical studies, the inter linkage amongst finance, globalization and growth is specified as:

$Y=f(F I N, G L O B)$

Where economic growth is represented by $Y$, FIN denotes financial development and $G L O B$ is globalization. Expressing equation (1) in econometric form becomes:

$$
Y_{i t}=\sigma+\pi F I N_{i t}+\eta G L O B_{i t}+\beta Z_{i t}+\mu_{i t}
$$

where $Y$ denote economic growth, $\sigma$ denotes country - specific intercept, FIN is financial development and GLOB is globalization while $i$ denotes the country, $t$ is the time period, error term is symbolized by $\mu_{i t}$ and $Z_{i t}$ denote the control variable (macroeconomic uncertainty (proxied by CPI-based inflation) and domestic investment (proxied by gross capital formation as a ratio of GDP)) because they have been empirically proven to have vital impact on economic growth (Osei and Kim (2020).

To probe the presence of globalization in finance-growth nexus, the technique of panel autoregressive distributive lag model (PARDL) developed by Pesaran et al. (1999) is utilized. This estimation technique has several merits over static models because it accounts for heterogeneity in a dynamic panel setting (Rafindadi, Muye \& Kaita, 2018; Samargandi, et al. 2015). Further, this method accommodate variables of different integration order; I (0) and/or I(1) (Rafindadi, Muye \& Kaita, 2018); and also, it generates reliable estimates in the presence of endogeneity (Chen \& Vujic, 2016; Chudik et al., 2013; Pesaran et al., 1999; Pesaran \& Smith, 1995). Lastly, the short-run and long-run models are estimated simultaneously (Pesaran et al., 1999). Thus, this technique gets rid of problem of slope heterogeneity across 
countries, order of integration in variables and cross- sectional dependence (Rafindadi, Muye \& Kaita, 2018; Chen \& Vujic, 2016).

The technique has 3 estimators namely, the mean group (MG), pooled mean group and dynamic fixed effect. The MG estimator assumes heterogeneity in all coefficients and uses the average of the long-run coefficients of each cross-section to estimate the long-run parameters. However, the dynamic fixed effect (DFE) estimator assumes homogeneity in all coefficients and incorporated the lagged term of the dependent variable as one of the independent variables. Lastly, for the pooled mean group (PMG) estimator, only the long-run slope coefficients are homogeneous while the short run parameters are heterogenous. The appropriateness of these estimators is decided using the Hausman test.

The general form of panel autoregressive distributed lag (ARDL) (p, q) is model as follows:

$Y_{i, t}=\sigma_{i}+\sum_{k=1}^{p} \pi_{i j} Y_{i, t-j}+\sum_{k=0}^{q} \phi_{i j}^{\prime} X_{i, t-j}+\mu_{i t}$

Where $X_{i, t}=\left(\operatorname{FIN}_{i, t}, \operatorname{GLOB}_{i, t}\right.$, Control $\left._{i, t}\right), \quad$ and Control $_{i, t}=\left(I N F_{i, t}, I N V_{i, t}\right)$

Where ${ }^{t}$ symbolize time element (annual), country index is represented by $i$ and $\sigma_{i}$ denotes country fixed effects. In addition, $k$ time lags. In equation (4), the dependent variable is denoted by $Y_{i t}$; the vector $X_{i t}$ represents financial development, globalization and control variables (investment and macroeconomic uncertainty). Equation (3) can be re-parameterized into:

$$
\Delta Y_{i, t}=\sigma_{i}+\phi_{i} Y_{i, t-k}+\vartheta_{i}^{\prime} X_{i, t}+\sum_{k=1}^{p} \pi_{i k} Y_{i, t-k}+\sum_{k=0}^{q} \theta_{i k}^{\prime} X_{i, t-k}+\mu_{i t}
$$

Where

$$
\begin{aligned}
& \phi_{i}=-1\left(1-\sum_{k=1}^{p} \gamma_{i k}\right) \\
& \vartheta_{i}=\frac{\sum_{k=0}^{q} \theta_{i k}}{\left(1-\sum_{k=1}^{p} \gamma_{i k}\right)}, \gamma_{i k}^{*}=-\sum_{n=k+1}^{p} \gamma_{i k} \text { and } \theta_{i k}^{*}=-\sum_{n=k+1}^{q} \theta_{i k}
\end{aligned}
$$

Equation [3.7] in Error correction form is specified as:

$$
\begin{aligned}
& \Delta Y_{i, t}=\sigma_{i}+\phi_{i}\left(Y_{i, t-j}-\vartheta_{i}^{\prime} X_{i, t}\right)+\sum_{k=1}^{p} \pi_{i k} Y_{i, t-k}+\sum_{k=0}^{p} \theta_{i k}^{\prime} X_{i, t-k}+\mu_{i t} \\
& \phi_{i}<0
\end{aligned}
$$

Where $\phi_{i}\left(Y_{i, t-j}-\vartheta_{i}^{\prime} X_{i, t}\right)$ is the adjustment in $Y_{i t}$ to the deviation from its long-run relationship and short-run coefficients linking $Y_{i t}$ with its lag values and other independent variables are $\gamma_{i j}^{*}$ and $\theta_{i j}^{*}$. In addition, $\phi_{i}$ is the error-correction coefficient estimates which 
measures the speed of adjustment of $Y_{i t}$ toward its long-run equilibrium in case of a change in any of the independent variables $X_{i t}$. In order to ensure that long run relationship exist among the variables, the speed of adjustment $\phi_{i}$ must be negative and significant.

\section{Result and Discussion}

This section focuses on result presentation. The descriptive statistics and correlation matrix gives first-hand descriptions of the relevant data employed in this study. Table 1 presents the result of the descriptive statistic and correlation matrix of 21 African economies spanning 1990 and 2017. From Table 1, the average income per capita is $\$ 3282.20$ and ranges between $\$ 14014.87$ and $\$ 164.33$. The mean values of financial and globalisation index are 0.1957 and 50.1258 while the average of investment and macroeconomic uncertainty are 21.17 and 25.47 respectively. Volatility in economic growth is higher than volatility stems in financial development and globalization index. The correlation matrix shows a positive association between growth and urbanization, which is not surprising for a heavily income per capita and financial development and globalization index. Similarly, we observe that growth and inflation are negatively related.

Table 1: Summary Statistics and Correlation

\begin{tabular}{cccccc}
\hline Variable & $\mathbf{N}$ & Mean & Std. Dev & Min & Max \\
\hline Y & 588 & 3282.20 & 3016.683 & 164.3366 & 14014.87 \\
FIN & 588 & 0.1957 & 0.1106 & 0.0645 & 0.6266 \\
GLOB & 588 & 50.1258 & 9.8571 & 22.356 & 72.354 \\
INV & 588 & 21.1779 & 10.2619 & 1.9833 & 61.4690 \\
INF & 588 & 25.4795 & 215.1075 & -11.6861 & 4145.106 \\
Y & 1.000 & & & & \\
FIN & 0.4627 & 1.0000 & & & \\
GLOB & 0.4038 & 0.6721 & 1.0000 & & 1.0000 \\
INV & 0.1322 & -0.0002 & 0.0802 & 1.0000 & -0.1547 \\
INF & -0.0418 & -0.0600 & -0.1089 & & \\
\hline
\end{tabular}

Note: Y, FIN, GLOB, INV, INF denote income per capita, financial development, globalization, investment (proxied by gross capital formation) and macroeconomic uncertainty (proxied by consumer price index) respectively.

In order to know the order of integration of the variables employed for this study, first generation panel unit root tests such as Levin, Lin and Chu (LLC), Im, Pesaran and Shin (IPS) and Breitung panel unit root tests are utilized. The empirical result of the panel unit root test is presented in Table 2. We observed that gross domestic product per capita (LY), globalization index (LGLOB) and investment (LINV) contain unit root while financial development index and macroeconomic uncertainty are found to be stationary at level. After the first difference, all the variables are stationary. This shows that the variables have a mixed order of integration. According to Pesaran et al. 1995, 1999, panel ARDL is applicable if variables contain a mixed order of integration, based on this, we proceed to evaluate the nexus between financial development and economic growth in the presence of globalization. 
Table 2: Panel Unit Root Test

\begin{tabular}{|c|c|c|c|c|c|c|}
\hline \multirow[b]{2}{*}{ Variables } & \multicolumn{2}{|c|}{ LLC Test } & \multicolumn{2}{|c|}{ IPS Test } & \multicolumn{2}{|c|}{ BREITUNG Test } \\
\hline & Level & First Diff & Level & First Diff & Level & First Diff \\
\hline IY & -1.6772 & $-14.3492 * * *$ & 0.0752 & $-13.1171 * * *$ & 1.4020 & $-6.5667 * * *$ \\
\hline FIN & $-5.0807 * *$ & $-20.9488 * * *$ & $-3.3693 * *$ & $-15.6927 * * *$ & $3.1917 * *$ & $-14.6132 * * *$ \\
\hline IGLOB & -2.3631 & $-18.7724 * * *$ & -1.6871 & $-13.5437 * * *$ & 6.2188 & $-19.8292 * * *$ \\
\hline IINV & -7.1196 & $-19.3023^{* * *}$ & -1.6878 & $-14.6279 * * *$ & -0.7454 & $-12.6797 * * *$ \\
\hline IINF & $-10.0543 * *$ & $-23.5173 * * *$ & $-2.5786 * *$ & $-14.017 * * *$ & $-5.5175^{* *}$ & $-9.6037 * * *$ \\
\hline
\end{tabular}

Note: Y, FIN, GLOB, INV, INF denote income per capita, financial development, globalization, investment (proxied by gross capital formation) and macroeconomic uncertainty (proxied by consumer price index) respectively. Note 2: $*^{* * *}, * *, *$ indicate statistical significance at $1 \%, 5 \%$ and $10 \%$ respectively. The null hypotheses of Levin, Lin and Chu, Im, Pesaran and Shin (IPS) and Breitung tests are that the underlying series are nonstationary.

In this study, cross dependence test developed by Pesaran (2004) is applied to check for cross-sectional dependence among the variables. The CD test is utilized because African countries tend to exhibit similar traits and are interconnected via trade, globalization due economic union and other networks. The result of the Pesaran CD (2004) cross dependency test is displayed in the first column of Table 3 and the result indicates that all variables considered in this study have cross-sectional bias problem. Since the performance of traditional unit root tests such as LLC, IPS, Breitung tests can be influence by the presence of cross dependence (Nathaniel et al. 2020; and Ahmed and Le, 2020). Thus, in order to overcome this problem, we employed Cross-Sectional Augmented Panel Unit Root (CIPS) and Cross-Sectional Augmented Dickey-Fuller (CADF) panel Unit root test of Pesaran (2007) which gives reliable and consistent result. The result of the CIPS and CADF panel unit root presented in Table 4 suggests that all the variables are stationary at level except economic growth (LY). After first difference, economic growth becomes stationary.

Table 3: Cross Dependency Test and Panel Unit Root Test

\begin{tabular}{|c|c|c|c|c|c|c|}
\hline \multirow[b]{2}{*}{ Variables } & \multicolumn{2}{|c|}{ CD Test } & \multicolumn{2}{|c|}{ CIPS Test } & \multicolumn{2}{|c|}{ CADF Test } \\
\hline & CD & Obs(corr) & Level & First Diff & Level & First Diff \\
\hline IY & $50.61 * * *$ & 0.828 & -1.807 & $-4.225 * * *$ & -1.810 & $-3.194 * * *$ \\
\hline FIN & $43.66 * * *$ & 0.587 & $-2.645^{* *}$ & $-5.344 * * *$ & $-2.467 * *$ & $-4.342 * * *$ \\
\hline IGLOB & $70.05 * * *$ & 0.914 & $-2.687 * *$ & $-5.066 * * *$ & $-2.719 * *$ & $-4.035 * * *$ \\
\hline IINV & $4.92 * *$ & 0.400 & $-2.485^{* *}$ & $-4.986 * * *$ & $-2.434 * *$ & $-3.729 * * *$ \\
\hline IINF & $13.43 * *$ & 0.273 & $-3.284 * * *$ & $-5.823 * * *$ & $-2.344 * *$ & $-4.863 * * *$ \\
\hline \multicolumn{7}{|c|}{$\begin{array}{l}\text { Note: Y, FIN, GLOB, INV, INF denote income per capita, financial development, globalization, investment (proxied by } \\
\text { gross capital formation) and macroeconomic uncertainty (proxied by consumer price index) respectively. Note } 2 \text { : } \\
* * *, * *, * \text { indicate statistical significance at } 1 \%, 5 \% \text { and } 10 \% \text { respectively. The null hypothesis of CD test states that } \\
\text { there exist no CD among sample countries while the alternative hypothesis states there exist CD among sample } \\
\text { countries. The null hypothesis for the CIPS and CADF unit root tests assumes homogeneous non-stationary as against } \\
\text { the alternative hypothesis of possible heterogeneous alternatives. }\end{array}$} \\
\hline
\end{tabular}

Table 4 report the result of the panel ARDL (pooled mean groug, mean group and dynamic fixed effect) on the nexus between financial development, globalization and economic growth among 21 African economies spanning 1990 and 2017. Hausman test is applied to select the best estimator among PMG, MG and DFE. The result of the Hausman test support the PMG 
estimator as the efficient estimator, then the use of a MG or DFE estimator is unsuitable. Thus, the interpretation of this study will be based on PMG estimator. The result of the PMG estimator indicates that financial development exerts a positive and significant impact on economic growth in both short and long run, that is, a $1 \%$ increase in financial development foster African economies by 2.451 and 0.302 percent in both long run and short run respectively. This finding validates the result of Botev and Jawadi (2019) that finance stimulate economic growth in developed countries but refutes the result of Muazu and Ibrahim (2018) and Redmond and Nasir (2020) whose study finds that financial development hinders SSA growth. The result supports the supply-leading hypothesis that a well-developed financial sector lessens transaction costs and augment economic growth. Furthermore, globalization has a positive and significant influence on economic growth in the long run though insignificant in the short run. The results indicates that globalization foster growth by $0.986 \%$ and $0.0975 \%$ in the long and short-term respectively. This outcome supports the study of Brueckner and Lederman (2015). This finding suggests that African economies attract more external financing and improves production processes which paves the way for economic development. The coefficient of physical capital investment is positive and significant in both short and long run, thus confirming the important role played by physical capital in African's growth. However, the coefficient of macroeconomic uncertainty (proxied by consumer price index) is negative and significant in the long run but insignificant in the short run. This implies that macroeconomic uncertainty impedes African economies. Lastly, a significant negative coefficient of the error correction is necessary to substantiate a statistically significant relationship over the long run. The results of empirical testing affirm a short- and long-run relationship between financial development, globalization and economic growth among African countries.

in OPEC countries. Table 4 suggests that error correction coefficient (ECM) is -0.0985 , which is significant at the $1 \%$ level, implying that a $9.85 \%$ adjustment takes place after temporal shocks in the long-run equilibrium relationships between economic growth, financial development and globalization.

Table 4: Panel ARDL Regression result

\begin{tabular}{lccc}
\hline Dep. Variable: LY & PMG & MG & DFE \\
\hline VARIABLES & & & \\
\hline Long-run Estimate & $2.451^{* * *}$ & 3.664 & 0.773 \\
LFIN & $(0.329)$ & $(2.610)$ & $(0.655)$ \\
& $0.986^{* * *}$ & $0.748^{*}$ & $1.618^{* * *}$ \\
LGLOB & $(0.0826)$ & $(0.402)$ & $(0.249)$ \\
& $0.129^{* * *}$ & 0.162 & $0.0993^{* * *}$ \\
LINV & $(0.0198)$ & $(0.106)$ & $(0.0353)$ \\
& $-0.0286^{* * *}$ & $-0.0590^{* *}$ & -0.0409 \\
LINF & $(0.00881)$ & $(0.0239)$ & $(0.0254)$ \\
& & & $-0.0729^{* * *}$ \\
Short run Estimate & $-0.0985^{* * *}$ & $-0.205^{* * *}$ & $(0.0124)$ \\
\hline ECT(-1) & $(0.0223)$ & $(0.0325)$ & $0.233^{* *}$
\end{tabular}


Vol. 2, No. 3, September 2021

\begin{tabular}{|c|c|c|c|}
\hline & $(0.139)$ & $(0.171)$ & $(0.0942)$ \\
\hline \multirow[t]{2}{*}{$\triangle L G L O B$} & 0.0975 & $0.126^{* *}$ & 0.0435 \\
\hline & $(0.0653)$ & $(0.0534)$ & $(0.0475)$ \\
\hline \multirow[t]{2}{*}{$\Delta L I N V$} & 0.00224 & -0.00103 & $0.00926^{* *}$ \\
\hline & $(0.0181)$ & $(0.0166)$ & $(0.00434)$ \\
\hline \multirow{2}{*}{$\Delta L I N F$} & -0.000466 & $-0.00370 * *$ & $-0.00424 * *$ \\
\hline & $(0.00196)$ & $(0.00182)$ & $(0.00174)$ \\
\hline \multirow[t]{2}{*}{ Constant } & $0.295 * * *$ & $0.981 * * *$ & 0.0876 \\
\hline & $(0.0708)$ & $(0.286)$ & $(0.0745)$ \\
\hline Observations & 567 & 567 & 567 \\
\hline Hausman & MG vs PMG & & PMG vs DFE \\
\hline Chi2(4) & 1.30 & & 1.01 \\
\hline Prob & 0.8613 & & 0.6821 \\
\hline
\end{tabular}

\section{Conclusion.}

This study aims to investigate the link between growth, financial development and globalization using a multivariate framework on panel data sets of 21 African countries from 1990 to 2017. The findings of this study are vital for understanding the relationship among financial development, globalization and economic growth in African countries. Particularly, our findings suggest that financial development and globalization plays a significant role in promoting economic growth of African countries. Further, results indicate that physical capital investment has an important role in accelerating economic performance of African economies. Based on these findings, it is important for African countries to promote globalization-financial development policies in order to have access to alternative sources of external financing and attract foreign investment that can spur growth of African countries.

\section{Reference.}

Adelowokan, O.A. (2012). Growth Effect of Education and Health Expenditure in Nigeria (1970-2010). African Journal of Scientific Research, 10(1), 510- 528.

Adeniyi, O., Oyinlola, M. A., Omisakin, O. A. \& Egwaikhide, F. O. (2015). Financial development and economic growth in Nigeria. Evidence from threshold modelling. Economic Analysis and Policy, 47, 11-21.

Ahmed, z. \& Le, H. P. (2020). Linking Information Communication Technology, trade globalization index, and $\mathrm{CO} 2$ emissions: evidence from advanced panel techniques. Environmental Science and Pollution Research 28(7), 1-12.

Ahmed, Z., \& Wang, Z., Mahmood, F., Hafeez, M. \& Ali, N. (2019). Doesglobalization increase the ecological footprint? Empirical evidence from Malaysia. Environmental Science and Pollution Research, 26, 18565- 18582. 
Ahmed, Z., Zhang, B. \& Cary, M. (2021). Linking economic globalization, economic growth, financial development, and ecological footprint: Evidence from symmetric and asymmetric ARDL. Ecological Indicators, 121, 1-12.

Alimi, A. S. \& Adediran, I. A. (2020). ICT diffusion and the finance-growth nexus: a panel analysis on ECOWAS countries. Future Business Journal, 6(16), 1-

Ang, J. B. (2008a). Determinants of foreign direct investment in Malaysia. Journal of Policy Modeling, 30(1), 185-189.

Atil, A., Nawaz, K., Lahiani, A. \& Roubaud, D. (2020). Are natural resources a blessing or a curse for financial development in Pakistan? The importance of oil prices, economic growth and economic globalization. Resources Policy, 67, 1-11.

Bagehot, W. (1873). A Description of the Money Market, Lombard Street, Homewood, IL: Richard D. Irwin (1962 Edition).

Balcilar, M., Gungor, H. and Olasehinde-Williams, G., 2019. On the Impact of globalization on financial development: a multi-country panel study. European Journal of Sustainable Development, 8, 350-364.

Botev, J. \& Jawadi, F. (2019). The nonlinear relationship between economic growth and financial development: evidence from developing, emerging and advanced economies. International Economics, 1-23.

Brueckner, M. \& Lederman, D. (2015). Trade openness and economic growth: panel data evidence from sub-Saharan Africa. Economica, 82 (s1), 1302-1323.

Chen, W. \& Vujic, S. (2016). A reassessment of the relationship between income inequality and economic growth: New Empirical Evidence from China.

Chudik, A., Mohaddes, k., Pesaran, M. H. \& Raissi, M. (2013). Debt, Inflation and Growth: Robust Estimation of Long-run Effects in Dynamic Panel Data Models. Globalization Institute Working Paper 162, Federal Reserve Bank of Dallas.

Dreher, A. (2006). Does globalization affect growth? Empirical evidence from a New Index. Applied Economics, 38(10), 1091-1060.

Faisal, F., Sulaiman, Y. \& Tursoy, T. (2020). Does an asymmetric nexus exist between financial deepening and natural resources for emerging economy? Evidence from multiple break cointegration test. Resources Policy, 64, 101512.

Gaies, B., Goutte, S. and Guesmi, K., (2019a). What interactions between financial globalization and instability? - growth in developing countries. Journal International Development, 31(1), 39-79.

Goldberg, P. K., \& Pavcnik, N. (2007). Distributional effects of globalization in developing countries. Journal of Economic Literature, 45(1), 39-82.

Goldsmith, R.W. (1969). Financial Structure and Development. Yale Univ. Press, New Haven CN.

Guan, J., Kirikkaleli, D., Bibi, A. \& Zhang, W. (2020). Natural resources rents nexuswith financial development in the presence of globalization: Is the resource curse exist or myth? Resources Policy, 66, 1-9. 
Gurley, J. \& Shaw, E. (1967). Financial Structure and Economic Development. Economic Development and Cultural Change, 34(2), 333-346.

Gygli, S., Haelg, F., Potrafke, N. and Sturm, J.-E. (2019). The KOF Globalization Index revisited. Rev. Int. Organ. 14 (3), 543-574.

Hammudeh, S., Sohag, K., Husain, S. Husain, S. H. \& Said, J. (2020). Nonlinearrelationship between economic growth and nuances of globalization with income stratification: Roles of financial development and governance. Economic Systems,

Ibrahim, M. \& Sare, Y. A. (2018). Determinants of financial development in Africa: How robust is the interactive effect of trade openness and human capital? Econ. Anal. Policy, 60, 18-26.

Kandil, M., Shahbaz, M. and Nasreen, S. (2015). The interaction between globalization and financial development: new evidence from panel cointegration and causality analysis. Empirical Economics, 49, 1317- 1339.

Kandil, M., Shahbaz, M., Mahalik, M. K. and Nguyen, D. K. (2017). The drivers ofeconomic growth in China and India: globalization or financial development? International Journal of Development Issues, 16, 54-84.

Khan, Z., Hussain, M., Shahbaz, M., Yang, S. \& Jiao, Z. (2020). Natural resource abundance, technological innovation, and human capital nexus with financial development: A case study of China. Resources Policy, 65, 101585.

Law, S.H., Tan, H.B. \& Azman-Saini, W.N.W. (2015). Globalization, InstitutionalReforms and Financial Development in East Asian Economies. The World Economy, 38, 379398.

Levine, R. (2005). Finance and growth: Theory and evidence. In P. Aghion, \& S. N. Durlauf (Eds.), Handbook of economic growth (Vol. 1A), 865-934. New York: North Holland.

Lucas, R. (1988). On the Mechanics of Economic Development. Journal of Economics, 22 (1): 3 - 42

Monetary

McKinnon, R. I. (1973). Money and Capital in Economic Development, Washington, DC: Brookings Institution.

Mills, M. (2009). Globalization and inequality. European Sociological Review, $25(1), 1-8$.

Mishkin, F. (2009). Globalization and financial development. Journal of Development Economics, 89, 164-169.

Muazu, I. \& Alagidede, P. (2018). The effect of financial development economic growth in sub-Saharan Africa. Journal of Policy Modelling, 20, 311-325.

Muhammad, N., Islam, A. \& Marashdeh, H. (2016). Financial development and economic growth: an empirical evidence from the GCC countries using static and dynamic panel data. Journal of Economic Finance, 40(4), 773-791.

Muye, I. M. and Muye, I. Y. (2017). Testing for causality among globalization, institution and financial development: further evidence from three economic blocs. Borsa Istanbul Review, 17, 117-132. 
Nasreen, S., Mahalik, M. K., Abbas, Q. and Shahbaz, M. (2015). The Interaction between Financial Development, Globalization, Institutions and Growth: the statistical Experience from 23 European Countries. MS Working Paper series. MS WP$11 / 2015$.

Nasreen, S., Mahalik, M. K., Shahbaz, M. \& Abbas, Q. (2020). How Do FinancialGlobalization, Institutions and Economic Growth Impact Financial SectorDevelopment in European Countries? Research in International Business and Finance, 54, 1-58.

Nathaniel S, Anyanwu O, Shah M (2020) Renewable energy, urbanization, and ecological footprint in the Middle East and North Africa region. Environ Sci Pollut Res 27:14601-14613

Osei, M. J. \& Kim, J. (2020). Foreign direct investment and economic growth: Is more financial development better? Economic Modelling, 93, 154-161.

Pesaran, H. \& Smith, R. (1995). Estimating Long-Run Relationships from Dynamic Heterogeneous Panels. Journal of Econometrics, 68 (1), 79 - 113

Pesaran, M. H. (2007). A simple panel unit root test in the presence of cross section dependence. J. Appl. Econ., 47, 265-312.

Pesaran, M. H., Shin, Y. \& Smith, R. P. (1999). Pooled Mean Group Estimation of Dynamic Heterogeneous Panels. Journal of the American Statistical Association, 94(446), 621-634.

Rafindadi, A. A., Muye, I. M. \& Kaita, R. A. (2018). The effects of FDI and energy consumption on environmental pollution in predominantlyresource-based economies of the GCC. Sustainable Energy Technologies and Assessments, 25, 126-137.

Redmond, T. \& Nasir, M. A. (2020). Role of natural resource abundance, international trade and financial development in the economic development of selected countries. Resources Policy, 66, 101591.

Roquez-Diaz, A. \& Escot, L. (2018). Relationship between trade openness and economic growth in Latin America: a causality analysis with heterogeneous panel data. Rev. Dev. Econ. 22 (2), 658-684.

Rousseau, P. L. \& Sylla, R. (2001). Financial systems, economic growth, and globalization. In: Globalization in Historical Perspective. National Bureau of Economic Research, 373-403.

Sahay, R., Čihák, M., N’Diaye, P., Barajas, A., Bi, R., Ayala, D., Gao, Y., Kyobe, A., Nguyen, L., Saborowski, C., Svirydzenka, K., and Yousefi, S. R. (2015). Rethinking Financial Deepening: Stability and Growth in Emerging Markets. International Monetary Fund Discussion Paper, SDN/15/08, 1-41.

Samargandi, N., Fidrmuc, J. \& Ghosh, S. (2015). Is the Relationship between Financial Development and Economic Growth Monotonic? Evidence from a Sample of Middle-Income Countries. World Development, 68, $66-81$.

Schumpeter, J. A. (1911). The Theory of Economic Development, Cambridge, $\quad$ MA: Harvard University Press 
Sethi, P., Chakrabarti, D. \& Bhattacharjee, S. (2020). Globalization,

financial development and economic growth: Perils on the environmental sustainability of an emerging economy. Journal of Policy Modeling, 42, 520-535.

Shahbaz, M., (2012). Does trade openness affect long run growth? Cointegration, causality and forecast error variance decomposition tests for Pakistan. Economic Modelling, $29,2325-2339$.

Shahbaz, M., Mallick, H., Mahalik, M. K. and Hammoudeh, S. (2018a). Is globalization detrimental to financial development? Further evidence from a very large emerging economy with significant orientation towards policies. Applied Economics, 50, 574-595.

Shahbaz, M., Nasir, M. A., Hille, E. \& Mahalik, M. K. (2020). UK's net-zero carbonemissions target: Investigating the potential role of economic growth,financial development, and R\&D expenditures based on historical data (1870-2017). Technological Forecasting \& Social Change, 161, 1-15.

Shaw, E. S. (1973). Financial Deepening in Economic Development, New York: Oxford University Press.

Song, C-Q., Chang, C-P. \& Gong, Q. (2020). Economic growth, corruption, and financial development: Global evidence. Economic Modelling, 94, 822- 830.

Wu, C-F., Huang, S-C., Chang, T., Chiou, C-C., Hsueh, H-P. (2020). The nexus offinancial development and economic growth across major Asian economies: Evidence from bootstrap ARDL testing and machine learning approach. Journal of Computational and Applied Mathematics, 372, 112660

Zaidi, S. A. H., Wei, Z., Gedikli, A., Zafarf, M. W., Hou, F. \& Iftikhar, Y. (2019). Theimpact of globalization, natural resources abundance, and human capital on financial development: Evidence from thirty-one OECD countries. Resources Policy, 64, $1-9$.

Zaidi, S. A. H., Zafar, M. W., Shahbaz, M. \& Hou, F. (2019). Dynamic linkages between globalization, financial development and carbon emissions: Evidence from Asia Pacific Economic Cooperation countries. Journal of Cleaner Production, 228, 533-543.

\section{Copyrights}

Copyright for this article is retained by the author(s), with first publication rights granted to the journal.

This is an open-access article distributed under the terms and conditions of the Creative Commons Attribution license (http://creativecommons.org/licenses/by/4.0/) 